\title{
DEFINITION, TYPES, SUSTAINABILTY AND RELATION OF TOURISM WITH ENVIRONMENT, LANDSCAPE PLANNING AND RECREATION
}

\author{
Emine Patan ${ }^{1}$ \\ Işık Sezen ${ }^{2}$
}

\begin{abstract}
Tourism can be defined to be the combination of events and relationships resulting from the travels and accommodation for temporary human activities lasting from at least two days to two years such as work, recreation, entertainment and sport. Sustainability is referred to the conservation and transfer of an existing thing to generation next in its present form. Sustainability concept in tourism is the evaluation of the sources used for tourism by considering this approach.

Tourism has a very close relationship with the environment we live in by positively or negatively affecting it. In the present study, the concepts of tourism, tourism types and sustainable tourism are evaluated and relationships between tourism and environment, landscape planning and recreation.
\end{abstract}

Key words: Definition, Sustainabilty, Tourism, Environment, Landscape Planning, Recreation.

\section{INTRODUCTION}

\section{Definition and characteristics of tourism}

According to Mieczkowski (1990), the word tourism is derived linguistically from Latin words such as "tornare" and "tornus", which mean turning around.European languages borrowed the word tourism from "tour" which means turning back to starting point in French and was transformed into "tourisme", "tourismo", "tourismus", "tourism", "tourism" in French, Italian, German, English, Russian (Y1lmaz, 1999).

Bayer (1992) stated that a generally accepted tourism definition belongs to International Association of Scientific Experts in Tourism (AIEST, 1954), which is the combination of all activities caused by travel and accommodation of people aiming not to earn money and settle permanently where they go (Erdem, 2007).

Development of tourism sector at a certain point is dependent strictly on the attractive elements the area in question shelters. Therefore, attractive characteristics are the most required elements constructing the base of today's tourism industry. Diversity in touristic activities and attracting centres increase today due to changing interests of people depending on developed attractive characteristics(Özgüç, 1994).

Tourism sources from individually or combined effect of visual, natural and cultural potentials. When such sources are employed efficiently, then tourism as the sector to be primary factor in the economic development of nations may also become a continuous income source. Tourism and recreation activities have significant effects on regional economies (Atayand Özaydın, 1996).

\footnotetext{
${ }^{1}$ Research Assistant, Department of Landscape Architecture, Faculty of Architecture, İstanbul Technical University, 34000, İstanbul, Turkey.

${ }^{2}$ Assistant Professor, Department of Landscape Architecture, Faculty of Architecture and Design, Atatürk University, Erzurum, Turkey.
} 
Usta (1997) defined tourism to be a social science studying and evaluating scientifically all the events and relationships resulting from travels and temporary accommodations out of permanent living area by employing sciences like economy, management, finance, accounting, policy, law, architecture, ecology, demography, psychology.

UNWTO sees tourism to be a travel in free time left behind working period and dependent services and relationships it causes like accommodation, eating - drinking, transportation and entertainment (Middleton 1998). Tourism was defined by United Nations Environment Program (UNEP) in 1963 to be all the events and relationships resulting from the travels and temporary and not income generating accommodations for at least 24 hours (Tolungüç, 1999).

According to Tunçand Sevin (2001), tourism as a concept is defined to be all the events and relationships caused by changes in location and accommodation of people as consumers with cultural, sportive, curiosity, health,work, adventure and religious aims.

Niray (2002) defined tourism similarly with the definition of UNEP but stated that a certain definition outlining tourism is not possible because of its complexity and multiaspect and conflicting interactions with other activities.

Gossling (2002) reported that most of the developing countries focused on tourism to create economicactivity diversity and additional sources. Tourism is the fastest growing and among the largest sectors in the world. It is fed primarily by natural, cultural and historical source values. Rapidly growing and having economical weight, tourism takes place in national policies and today ecological environments can be evaluated for this aim and ecology and economy are directed in its scope(Bulut, 2006). Tan (2013) suggested that in tourism people running away from monotone urban life show interests in in the areas conserving natural, cultural and visual values. Visitors wish to know societies bearing different cultural values and therefore the locations achieving to conserve their natural and cultural values are preferred more.

\section{Types of Tourism}

Mill and Morrison (1985) classified tourism into categories convenient with the aims in different types and attractive elements for tourism are connected to be climate, culture, history, ethnical features and accessibility.Gunn (1988) evaluated different parameters to classify tourism and stated that attractive elements can determine the types of accommodation. Such classification includes tour route attractions andlong term accommodationattractions.

\section{Sustainable tourism}

According to Gülez (1988), development of tourism cannot be against natural protection. Tourism and nature are two contrast concepts which have to agree. Without protecting nature tourism activities cannot be performed sustainably therefore soft tourism should be introduced where these two contrast concepts complete each other.

Human population increases too fast to use existing natural and cultural sources sustainably. Today natural, cultural and visual sources are under threat due to their 
unplanned use for tourism and recreation. Sustainability in tourism is the evaluation of sources used for touristic aims in sustainability understanding (Mikaeili-Tabrizi, 1996).

Nepal (2000) stated that UNWTO defined sustainable tourism to be a tourism form which improves quality of life in hosting country, offers high service quality experience for visitors and increases environmental quality of the areas. Sustainable tourism understanding evaluates the sources in a complementary way and considers planning and management together.

According to Kalem (2001), sustainable tourism, defined to be a tourism understanding which requires protection and development of possibilities for future while meeting today's needs in the areas hosting tourists, aims to perform touristic activities in convenience with natural and cultural environment and not to sacrifice local values for the development of tourism but to benefit from them.

It is essential in sustainable tourism to protect and use natural, cultural and visual sources. In the evaluation and use of such sources, an absolute balance must be constituted between economicand ecologic concepts. Use by protecting principle plays important role in the foundation of this balance (Erdoğan 2003).

Having placed on world agenda with 1992 Rio Conference, "sustainable development" concept needs to be applied in all sectors.Sustainable development is the continuation of economic development without harming environmental values and thus sustainable tourismmay be the increase of tourism capacity and the quality of tourism products without negatively affecting natural and human resources feeding the sector (Uçkunand Türkay, 2004).

\section{Relationship between tourism and environment}

Atayand Özaydın (1996) stated that base of tourism is environment. Environment is the combination of natural, cultural and visual sources. Natural sources refer to water reserves like seas, rivers and lake, areas with protection status, forests and coppice forests, natural wonders and interesting formations. Cultural sources include monumental structures belonging to past and today's civilisations, civil architecture examples, historical urban tissues, archaeological sites, past and living cultures and folklores (Bulut, 2006).

There are three different conceptual relationships between a tourism type based on nature and natural sources nature protection which are conflict, coexistence and symbiosis (Pekcan 2002).Environment supplies the source obligatory for tourism and is basically divided into two definitions which are natural environment to formation of which human beings do not have any contribution and artificial environment human beings formed using natural environment sources. Tourism can affect both types of environment (Erdoğan, 2003).

Degree of the contribution of tourism to national economy shows the development of tourism in a country. Any kind of expense made in tourism sector can create a movement in economy and affect national economies in various forms. As economic importance of tourism grows its social and environmental effects also increase. Research shows environmental protection is required in the development of tourism (Külekçi, 2012). 


\section{Relationship between tourismand landscape planning}

Kuntay (2004) stated that unfavourable effects of tourism on natural and culturalvalues should be reduced to minimum. For the sustainability of tourismnatural and culturalresources should be protected and improved by making landscape planning decisions.As stated by Christopher (1979), in making protection - use decisions, each site/landscape must be given character using their own events and sustaining their background.

Use - protection strategies should be developed before landscape/physical plans. Today plans are seen to be the arrangement of uses in a given area, however, in order to catch the agenda in consistently developing world, detailed perspective and strategies to realise decisions should be developed by collecting data about the area.

Usluand Kiper (2005) reported that in tourismculturaldifferences and local identities are attractive for tourists and as local products they are presented to them. In this respect, protection of unique natural and cultural landscape elements and their identity in an area is an important step to develop sustainable tourism in the mentioned area. For this aim protection of urban or rural tourism potentials requires the protection and improvement of unique values like plant tissue, architectural characteristics etc. which are convenient to unique landscape values.

\section{Relationship between tourismand recreation}

According to Altan (1984), recreation is composed of re and create meaning creating again. As a term, it refers to free time activities regaining or refreshing someone physically or psychologically. In general it is defined to be an extensive action including various activities such as relaxing, entertainment, evaluation of free time and walking around.

Edginton and Ford (1985) stated that in modern meaning, recreation is a social institution, collection of information and a professional study field independent from work, meeting important needs of people and full and happiness inspiring living tool. From this perspective, recreation can be defined to be activities people do voluntarily in their free time and are satisfied individually.

Most important aspect of recreation activities is that participants of theseactivates adopt them as recreation activities consciously and thus, the advantage of such an approach is to know which activity is performed where, when and how long (Sağcan, 1986).

According to Karaküçük (1995), recreation is a set of voluntary, willing, individual or group activities performed by humans to protect, regain or survive physical and psychological well-being affected badly under heavy working load, routine life style and unfavourable environmental effects or to entertain in independent and inbound leisure time without working to provide individual satisfaction and out of the time for obligatory needs.

Gündüz (1998) evaluated various activities under the headline of recreation performed to refresh the body and psychology torn in daily life. Recreationis thought in many times to be a kind of occupation or pure entertainment showing differences from the habits of daily 
life. There are several definitions in addition to general definitions of recreation(Özel, 2004).

According to Koçand Şahin (1999), recreation is all the activities performed in spare times willingly to refresh humans depending on the social, economic and cultural conditions and opportunities. As human gets away from nature and lives in urbanized cultural areas their instinct directs them to relax and refresh.

Karaküçük (1999) classified recreation based on its functions and other various criteria. Whatever the aims and desire for recreation an individual has, there is always a suitable recreation type for her $/ \mathrm{him}$. When considered the variety of human needs and desires and recreation types meeting them, then itcan be stated that no certain grouping is possible for the classification of recreation.

Topuzlu (1989) defined main resource of the relationships between tourismand recreation to be leisure time when they are both performed. Even though there are many different expressions about the definitions of the relationships between these two concepts, some may be given to outline the general frame.

According to Bayer (1992), recreation and tourism are the concepts to complete each other and be evaluated together. Scientific works on recreational activities have been introduced in literature for the last 50 or 60 years, but recreational tourism planning is a more recent concept.

According to Gürdal (1997), basis of all planned and completed worksaimed with recreation and tourismis use and protection of natural and culturalsource values. Tourism and recreation are two concepts which can be developed in one other's outlines and use the same source values on the basis. The important thing to be realised in this respect is to research how to develop recreational possibilities and use them for tourism in settlements with natural and cultural potentials without deteriorating natural development process.

Özkan (2002) stated that tourismand recreation ingeneral increase human quality of life.In expanding urban areas due to increasing human population serious environmental problems began to be seen. Such developments also increased the needs of today's people for recreation and people desire to get away from the environments having negative impacts on their life is short periods and prefer to go to natural or semi-natural landscapes (rural areas).

\section{CONCLUSION}

In several related studies one of the largest and industrial forces, tourism can again be related to the development in many studies. Tourism is a very effective tool to promote countries undertaking roles to show their natural, cultural, historical, archaeological and folkloric values.

Tourism is the basic indicator of civilisation and social welfare. In order to make tourism sustainable existing natural and cultural values should be protected and transferred to generation next. Classification and types of tourism show diversity and many researchers 
tried to classify tourism types by considering its different aspects. Since tourism activities are performed in living environment, a strict relationship is present between them. Tourism can affect environment both positively and negatively and tourism activities may both harm or improve environment depending on their violence.

When evaluating the relationship between tourism and landscape planning, tourism needs to protect and improve natural and cultural sources for its sustainabilityand to do this, decisions in landscape planning should be efficient.Tourismand recreation were introduced for similar reasons but have different aspects and became similar concepts supporting each other, developing in one other's border and using the same source values. Both of them are performed in rural and urban areas and use and sustain natural and cultural source values.

It is suggested as a conclusion that there is a strong relationship between tourism and environment, landscape and recreation, such a relationship positively or negatively interacts, all natural and cultural source values should be protected and transferred to generation next in order to achieve the sustainability of tourism, environment and landscape and efficiency of the decisions in landscape plans is important.

\section{REFERENCES}

1. Altan, T., 1984. Kırsal Rekreasyon Alan Planlaması. Çukurova Üniversitesi, Ziraat Fakültesi Ders Kitabı No: 12, 184s, Adana.

2. Atay, F. ve Özaydın G., 1996. Turizm Amaçlı Kullanımlar Doğalve Yapay Alanları Nasıl Tüketiyor? Türkiye’de 19. Dünya Şehir cilik Günü Kolokyum Bildiri Kitab1, Mimar Sinan Üniversitesi, Şehirve Bölge Planlama Bölümü Yayını, İstanbul.185

3. Bayer, M. Z., 1992. Turizme Giriş. İşletme Fakültesi Yayın No: 253, İşletme İktisadı Enstitüsü Yayın No: 146, 230s, İstanbul.

4. Bulut Z., 2006. Kemaliye (Erzincan) İlçesive Yakın Çevresinin Alternatif Turizm Kapsaminda Rekreasyonel Turizm Potansiyelinin Belirlenmesi. Doktora Tezi, Atatürk Üniversitesi Fen Bilimleri Enstitüsü, Erzurum.

5. Christopher, A. 1979. The Timeless Way of Building. Oxford University Press, NewYork. Edginton, C.R., Ford, P.M., 1985. Leadership in Recreation and Leisure Service Organisations. Wiley, 448 s, New York.

6. Erdem, B. 2007. Sivas Kenti Doğalve Kültürel Değerlerinin Peyzaj Mimarlığıve Turizm Açısından Değerlendirilmesi. Yüksek Lisans Tezi, Ankara Üniversitesi Fen Bilimleri Enstitüsü Peyzaj Mimarlığı Anabilim Dalı, 180 s., Ankara.

7. Erdoğan, N., 2003. Çevreve (Eko) Turizm. Erk Yayınevi, 317s., Ankara.

8. Gossling, S., 2002. The consequences of tourism for sustainable water use on a Tropical Island: Zanzibar, Tanzania. Journal of Environmental Management, 6(12), 179-191.

9. Gunn, C.A., 1988. Vacation scape - Designing Tourist Regions. Van Nostrand Reinhold Co., New York.

10. Gülez, S., 1988. Doğa Korumave Turizm, Uzlaşması Gereken İki Zit Olgu. Turizm Y1llı̆̆1, Ankara.

11. Gündüz, S., 1998. Koruma-Kullanım İlkeleri Çerçevesinde Beynam Muhafaza Ormanı'nın Rekreasyonel Taşıma Kapasitesinin Saptanma s1 Üzerine Bir Araştırma. AÜ Fen Bilimleri Enstitüsü Peyzaj Mimarlığı Anabilim Dalı, Yüksek Lisans Tezi (Basılmamış), Ankara. 
12. Gürdal, M., 1997. Çanakkale İli'nin 2000'li Y1llarda Türkiye'de Sürdürülebilir Turizmve Kalkınma Olgusu İçindeki Yerive Önemi. Yerleşimve Çevre Sorunları: Çanakkale İli Sempozyumu Bildiriler Kitab1, DEÜ Mühendislik Fakültesi Çevre Mühendisliği Bölümü, 9-13 Eylül 1996, İzmir.

13. Kalem, S. 2001. Doğalve Kültürel Değerlerin Korunabilmesi İçin Turizm Potansiyelinin Belirlenmesinde Bir Yöntem Yaklaşımıve Kastamonu İli Kıyı Bölgesive Yakın Çevresinde Uygulanması. Doktora Tezi, Ankara Üniversitesi Fen Bilimleri Enstitüsü Peyzaj Mimarlığı Anabilim Dalı, 271 s., Ankara.

14. Karaküçük, S., 1999. Rekreasyon - Boş Zamanları Değerlendirme. Bağırgan Yayınevi, 3.Bask1, 410s., Ankara.

15. Koç, N., Şahin, Ş., 1999. Kırsal Peyzaj Planlaması. Ankara Üniversitesi Ziraat Fakültesi Yayını No:1509, 275s, Ankara.

16. Kuntay, O. 2004. Sürdürülebilir Turizm Planlamas1. Alp Yayınevi, Yayın No: 21, Turizm Serisi: 1; Ankara. 187

17. Külekçi, E., A., 2012. Oltuve Olur (Erzurum) İlçeleri Doğalve Kültürel Kaynaklarının Ekoturizm Açısından Değerlendirilmesi. Atatürk Üniversitesi Fen Bilimleri Enstitüsü Peyzaj Mimarlığı Ana Bilim Dalı, Doktora Tezi, Erzurum.

18. Middleton, V., Hawkins, R., 1998. Sustainable Tourism. A Marketing Perspective, Butterworth-Heinemann, Oxford.

19. Mikaeili-Tabrizi, A. R., 1996. Gilanİli'nde Rekreasyonel Alan Kullanımlarının Fiziksel Planlaması Üzerine Bir Araştırma. Doktora Tezi, Çukurova Üniversitesi, Fen Bilimleri Enstitüsü, Adana.

20. Mill, R.C., Morrison, A.M., 1985. The Tourism System: An Introductory Text. Prentice-Hall International Editions, 300-302, New Jersey.

21. Nepal, S. K., 2000. Tourism in Protected Areas the Nepalese Himalaya. Annals of Tourism Research, Vol:27 No:3 P:661-681.

22. Niray, N., 2002. Turizm Küreselleşme İlişkisive Tekelleşme Eğilimi. TC Turizm Bakanlığı, II. Turizm Şurası Bildiriler Kitabı (III. cilt), 12-14 Nisan, s: 241-252, Ankara.

23. Özel, A. E. 2004. Çanakkale İli Doğalve Kültürel Potansiyelinin Turizmve Rekreasyonel Kullanım Yönünden İncelenmesi. Yüksek Lisans Tezi. Çanakkale Onsekiz Mart Üniversitesi Fen Bilimleri Enstitüsü Peyzaj Mimarlığı Anabilim Dalı, 146 s., Çanakkale.

24. Özgüç, N., 1994. Turizm Coğrafyası. İÜ İletişim Fakültesi Yayınları, Üniversite Yayın No: 3821, FakülteYayın No: 3203, İstanbul.

25. Özkan, M.B., 2002 Özkan, Kırsal Rekreasyon Alan Planlamas1, Ege Üniversitesi Ders Notlar1, s. 52, İzmir.

26. Pekcan, C. 2002. Gökçeadave Bozcaada'nın Turizm Potansiyelinin Tespitive Adalarda Turizmin Gelişme Olanakları. Yüksek Lisans Tezi (Basılmamış). Çanakkale Onsekiz Mart Üniversitesi Sosyal Bilimler Enstitüsü Turizm İşletmeciliği Anabilim Dalı, Çanakkale.

27. Sağcan, M., 1986. Rekreasyonve Turizm. Cumhuriyet Basımevi, İzmir.

28. Tan, A. 2013. Samsun Kentive Yakın Çevresinin Doğalve Kültürel Peyzaj Özelliklerinin Turizm Potansiyeli Açısından İrdelenmesi. Yüksek Lisans Tezi. Ankara Üniversitesi Fen Bilimleri Enstitüsü Peyzaj Mimarlığı Ana Bilim Dalı, Ankara.

29. Tolungüç, A., 1999. Turizm Olgusuve Türk Turizmi. Ankara: Media Cat.

30. Topay, M., 2003. Bartın-Uluyayla Peyzaj Özelliklerinin Rekreasyon - 
Turizm Kullanımları Açısından Değiştirilmesi Üzerinde Bir Araştırma, Fen Bilimleri Enstitüsü, Doktora Tezi, 210s.

31. Topuzlu, F. K., 1989. Konaklama Tesislerinin Yapımve İşletmesi Sürecinde Rekreasyon Faaliyetlerine Yönelik Fiziksel Uygulamaların Teorik Nedenleri. Türkiye'de Son 10 Yılda Turizm Yapıları Sempozyumu, Yıld1z Üniversitesi, Ankara.

32. Uçkun, C.G., Türkay, O., 2004. İç Turizmi Canlandırmaya Yönelik Bir Pazarlama Önerisi: Erken Rezervasyon. Pazarlama Dünyas1, 18(48-51).

33. Uslu, A. ve Kiper, T. 2005. Kültür Turizminin Yerel Kimlikve Peyzaj Değerlerine Etkisi. Kırsal Çevre Yıllığı, 23-39.

34. Yilmaz, O., 1999. Turizmve Ticari Rekreasyon. AÜ Ziraat Fakültesi Peyzaj Mimarlığı Bölümü, Lisans Ders Notları, Ankara. 